\title{
Financialization of Commodity Market
}

\author{
Marcin Złoty \\ University of Lodz \\ 90-255, 3/5 POW Street, \\ Lodz Poland \\ e-mail:marcin.zloty@uni.lodz.pl
}

\begin{abstract}
:
The aim of the article is to present possible consequences caused by the development of commodity market financialization understood by the influence of financial investor's speculation. Also the task of elaboration is to outline the existence of financial factors in the price creation process of commodities. The existing impact of financialization on the volatility of commodity prices significantly modifies the market. The results of the research and analyzes carried out indicate a similarity in the behavior of the markets of commodities. The situation results from the redistribution of the risk of financial investors who having a few goods in the investment portfolio, next to large transaction volumes affect the unification of price trends. Price shaping factors are being transformed. The decrease importance of supply or consumption in the context of the commodities market changes its form. The growing influence of investors who create numerous speculations transforms the market. Trade in futures contracts affects the level of commodities prices.

Keywords: commodities, financialization, investment, speculations.
\end{abstract}

\section{Introduction}

Financialization is a pioneering and new process that has recently begun to shape new rules in economics. The process consists of increasing the importance of the financial sector in the economy. The transformation of various assets into investment instruments permeates their structure of primary destination [2]. The commodities cease to fulfill the role of satisfying hunger or generating energy, but there are also assets similar to stock exchange companies that can be sold and bought. The study focuses on factors influencing the price of commodities. The analyzed commodities are gold, silver, copper, crude oil and natural gas. These commodities have the largest volumes on the world futures market. The research period is the data from 2000-2018 on a monthly basis. Data on the tested goods come from the Thomson Reuters database. The survey methodology includes elements of descriptive statistics, a comparison of changes in the price level of the assets with unexplored indexes, measures of the dynamics of phenomena and Pearson's linear correlation study. The research hypothesis is the impact of concluding futures contracts on the price of commodities. The verification of the influence of investors on the futures exchange market in price formation is the main goal of the article. The increase volume of trade in commodities on electronic 
exchange market fundamentally modifies the structure of the market, making the analyzed assets into speculative financial instruments.

\section{Financialization}

Financialization began at the end of the twentieth century in the United States. Mark the increase in the importance of the financial sector in the economy. It is also understood as the overgrowth the size of the financial market over the production sector. The process began to penetrate more and more spheres of the economy. Now, many assets are traded on global exchange [6]. The emergence of innovative financial instruments has absorbed assets from various markets. Futures, forward, swaps or options contracts include the trade of goods such as metals and food products. The combination of assets from different areas makes the financial sector even more extensive and liquid [4]. Condensation of many types of assets in one place, i.e. shares, bonds and commodities may lead to their harmonization in terms of demand and supply. Unification may rely on similar price trends of various groups of assets, decreasing the role of real economy factors such as production, exports, imports, harvest size, weather conditions and market trends. The volume of futures contracts, meaning the supply and demand of e-commerce on international exchanges, gains in importance [11]. The reason for the radical progress of financialization in the economy is the significant development of capitalism that can be observed from the 1960s. The increase of the efficiency ethos is transformed by the hitherto concept of entrepreneurship. Effectiveness understood in the sense of financialization consists in an attempt to maximize economic activities at the technical and economic level of subordinated financial efficiency [7]. The major change in the investment and speculation in the sense of effectiveness is the amount of planned revenues. Until some time, investors planned the income they would like to get. Currently, financialization outlines an unlimited profit that never ends. The avidity of profit maximization is able to distort the markets, including the commodities sector [15]. Trade in the commodities without production, extraction or later consumption and use shows the unrealisation of the economy which only starts to take on commodities character.

The analyzed process leads to an increase in transactions of a financial nature. The unceasing repetition of purchase and sale of the same asset by a single entity shows the stock exchange nature of commodities trading. Investors are not interested in using the traded goods but in making the difference resulting from the spread. The activity of speculators blurs the boundary between trade, investment and consumption [3]. This leads to a conflict between the financial, industrial and labor market. Deregulation of financial markets and the increasing liberalization of cash flows are factors that intensify the process of financing. The development of modern IT solutions is also an important aspect of the development and expansion of financial market activities [13]. Lack of legal regulations regarding trading in shares or commodities encourages more entities to deal with many markets of the plane of unlimited speculation. With the described process, commodities become an investment asset that is not characterized by its physical utility. Structural changes indicate the feat of the process. The likeness of commodities with stocks or bonds affects the side of their demand and supply [16].

Financialization can also be understood as an increase in the allocation of monetary resources to the financial sector than in the production, industry or services sector [14]. Economic development has so far consisted of three stages. At the beginning of economic development, agriculture was important. As the countries got rich, there was a shift to the industrial sector. The last stage of development were services. Financialization from the end of the twentieth century creates a different dimension of the concept of development and transformations of the economy [1]. This increase in the number of financial instruments, the volume of transactions or open positions on the stock market is to determine the economic level. The size of conglomerates measured by the assets it owns is also a determinant that leads the perception of the national economy. The problem is that in the event of a financial crisis, the interconnected markets - stock 
markets, currencies, bonds or stocks measured in currencies may turn out to be worthless assets in an instant. Too much merger of economies with a financial crisis poses a lot of danger in the event of an economic crisis [15]. The occurrence of a domino effect in such a situation may lead to a tragic financial situation and a drop in the value of many assets, not only financial ones.

Financialization of the commodity market involves the influence of virtual exchange factors on the valuation of these goods. Futures transactions on the market currently have the largest impact. Their enormous scale leads to the creation of commodity prices and a decrease in real economy factors such as demand and supply.

\section{Commodity Market}

Since the beginning of the global economy, the commodity market has been an extremely important element in economic development. Assets, such as gold or silver have already had a lot of functions in the antiquity like a measure of value, a means of payment, a thesaurisation or a medium of exchange. As the historical graphs of gold, platinum or silver prices show, these assets have always been a protection against inflation. Precious metals have a more stable value than a lot of international currencies. However, this state of affairs is transformed and modified. A long-term risk premium or nature similar to the stock market means that the commodities become the investor's demand for assets [19].

In the last 40 years, the commodity market has significantly changed. The market modification depends to a large extent on the financing process. The growing role of financial investors means that real supply and demand for commodities is not important in shaping prices. Another significant direction of changes in the process of the impact of the financing process on the commodities market is the increase in the number of listed assets. With each passing year, there are more goods that can become the instigator of trading in commodities [12].

The enormous inflow of capital to the sector modifies it into a capitalist creation similar to the enterprise stock market. Redistribution of risk by investing in various types of assets leads to a similar trend of prices [17]. Large-scale investment in commodity aimed at reducing the risk of investment in finances leads to analogous and very similar shaping of the markets of particular commodity groups. An example of activity over the years allow to present this fact. Chart 1 illustrates the historical price formation of various commodity groups over the years, from early 1960 to 2018 . The period includes monthly data.

Figure 1. Forming prices of agricultural products, groceries, minerals and metals and whole group over the years 1960-2018.

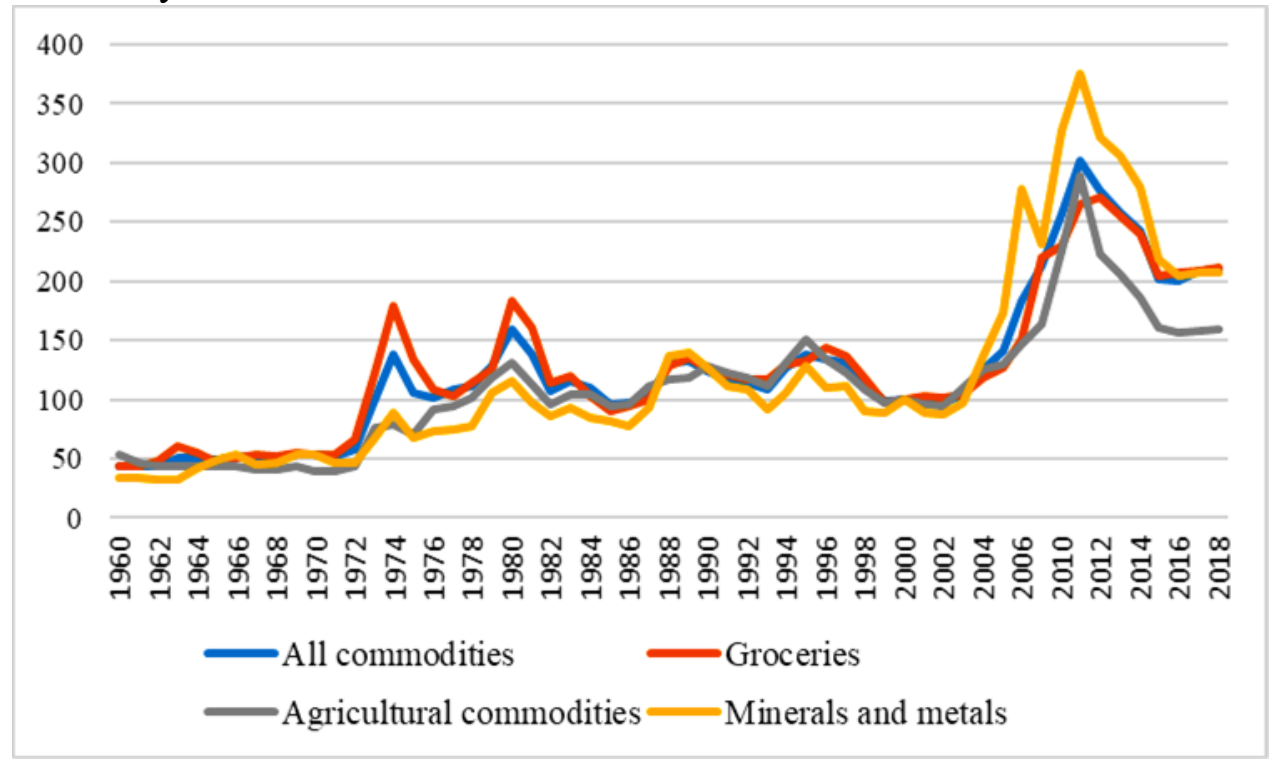

Source: Own work based on www.unctadstat.unctad.org [18]. 
The presented chart shows significant dependence between the studied groups of goods. Powerful and similar tendencies can be observed from the beginning of the 1960s. The period of the economic crisis of 2008-2011 led to slight delamination between individual groups of assets. However, after the economic turmoil is over, there is a return to the pre-crisis tendency, i.e. characterized by similar price movements. There is also a growing relationship between the analyzed commodities and the stock market. Common tendencies between the two separate markets are beginning to take on similar trends [9]. The high connection between commodities it does not result from substitution or complementarity but be connected with transactions on the futures contracts exchange.

To fairly present the level of dependencies between commodities, it is worth focusing on commodities whose turnover on the futures market was the highest (gold, silver, copper, WTI crude oil and natural gas). Statistics were showed in table 1.

Table 1. The number of futures contracts concluded in 2018 on the world commodity market.

\begin{tabular}{ll}
\hline COMMODITIES & $\begin{array}{l}\text { FUTURES } \\
\text { CONTRACTS }\end{array}$ \\
\hline WTI crude oil & 147950000 \\
\hline Natural gas & 39360000 \\
\hline Gold & 425320 \\
\hline Copper & 223660 \\
\hline Silver & 165430
\end{tabular}

Source: Own work based on Thomson Reuters database.

The study of the correlation coefficient will cover the years 2000-2018 when the financialization process has developed most. The analyzed period is based on monthly data. The collinearity level will be presented on the substitution of Pearson's linear correlation study. It is showed in table 2.

The significance of the linear correlation coefficients was verified by the $U$ test.

$\mathrm{U}=\frac{\rho}{1-\rho^{2}}-\sqrt{\mathrm{T}}$

$\mathrm{U} \sim \mathrm{N}(0,1)$, critical value $\pm 1,96$, significance level $\alpha=0,05$

$\mathrm{T}$ - number of observations (216), $\rho$ - correlation coefficient

Table 2. Correlation coefficient between the prices of analyzed commodities in the years 20002018.

\begin{tabular}{|l|l|l|l|l|l|}
\hline & Gold & Oil & Copper & Gas & Silver \\
\hline Gold & 1 & & & & \\
\hline \multirow{2}{*}{ Oil } & $0,823^{*}$ & 1 & & & \\
\hline \multirow{2}{*}{ Copper } & $\begin{array}{l}0,12,145] \\
\text { Natural gas } \\
{[-12,269]}\end{array}$ & $\begin{array}{l}0,893^{*} \\
{[-10,288]}\end{array}$ & 1 & & \\
\hline \multirow{2}{*}{ Silver } & $\begin{array}{l}0,382^{*} \\
{[-14,245]}\end{array}$ & $\begin{array}{l}0,112^{*} \\
{[-14,586]}\end{array}$ & $\begin{array}{l}0,023^{*} \\
{[-14,673]}\end{array}$ & 1 & \\
$0,947^{*}$ & $\begin{array}{l}0,831^{*} \\
{[-12,011]}\end{array}$ & $\begin{array}{l}0,844^{*} \\
{[-11,763]}\end{array}$ & $\begin{array}{l}-0,252^{*} \\
{[-14,966]}\end{array}$ & 1 \\
\hline
\end{tabular}

Source: Own work based on Thomson Reuters database.

* Values are statistically significant at level $\alpha=0,05$, in square brackets are critical values.

The high correlation between silver and gold is not astonishment, but the high level of correlation among other types of assets is curious. The correlation tested is the highest when the results are close to 1 . In the case of values close to 0 , there is no relationship between the assets. Negative 
values represent the occurrence of inversely proportional forces. The level of collinearity in the analyzed period of time between oil and gold is above 0,8 , which indicates a strong assimilation of markets. A similar situation occurs in the case of steam with oil and silver. A high correlation can be observed in the case of a pair of silver and copper, where the coefficient of dependence is 0,84 . There is no dependence in the case of gas and copper, where the correlation coefficient is close to zero. The opposite relationship is low in the case of silver and gas, where the correlation value is negative what shows opposite tendencies.

The presented table shows dealing with similar trends in shaping the prices of many commodities assets. There are commodities that do not show similar relations but the example of copper and oil shows that assets that are not substitute or complementary products exhibit similar behavior on the market. The growing volumes of transactions make the individual commodity markets similar [16]. The high correlation between these goods is also partly due to the fact that financial investors value them based on certain forecasts of future economic growth in the global market. The information obtained about economic activity has an impact on the process of increasing the prices of both commodities. The price creation process is intricate and full of various dependencies. Progressive financialization penetrates the process of volatility of commodities on the market. This situation may have a cause in the manifested growth of speculators on the commodity. The progressing financialization of the commodity market will transform the market into a trading platform similar to the stock market, where the profit resulting from the difference in purchase and sales is significant, not the functionality of commodities as it was some time ago.

The decrease in the significance of commodity producers in the context of price formation shows the nature of analyzed process. The dependence of setting prices on futures market is currently one of the major price determinants [10]. The factor that is responsible for the dependence of commodities on each other is also predictability. An attempt to predict or forecast prices based on the behavior of the forward market indicates innovative changes in the factors affecting commodities prices [5].

Process describes the financial market's impact on the economy. One of the key markets of the financial sector is the currency market. The influence of the level of international currency quotation is a key factor in the prices of a few assets. Analyzing the process of financialization the commodity market, it is extremely significant to trace the level of correlation between commodities prices and the currency in which these assets are listed on the market exchange. All assets covered by the survey are expressed in USD, which is why this currency will be a collinearity meter. Described sets have been presented in the table number 3.

Table 3. The level of correlation between the US dollar and the prices of the analyzed commodities in the years 2000-2018.

\begin{tabular}{|l|l|}
\hline Commodities & $\begin{array}{l}\text { The level of correlation } \\
\text { with the US dollar }\end{array}$ \\
\hline Gold & $0,483^{*}[-14,045]$ \\
\hline Silver & $0,564^{*}[-13,855]$ \\
\hline Copper & $0,751^{*}[-12,987]$ \\
\hline Oil WTI & $0,753^{*}[-12,961]$ \\
\hline Gas oil & $0,342^{*}[-14,306]$ \\
\hline
\end{tabular}

Source: Own work based on Thomson Reuters database.

* Values are statistically significant at level $\alpha=0,05$, in square brackets are critical values.

The level of correlation has been verified for the analyzed commodities over 18 years from the beginning of the 20th century. A level of correlation close to 1 indicates a very strong correlation, while results close to zero indicate that there is no convergence between the analyzed structures. The highest level of correlation was recorded for copper and crude oil. Interestingly, the level of correlation between the dollar and these commodities is almost identical and amounts to 0,75 . The 
result indicates a strong dependence of copper and oil on the US dollar. The level of silver correlation is also high and amounts to 0,57 and the level of gold and USD dollar dependence was slightly less, i.e. 0,5 . The lowest level of linear correlation was for the ratio of natural gas which was 0,34 . Such value does not indicate a mutual relationship between the analyzed assets and the dollar. The situation may have a cause in the political determinants of Russia's operations, which is the main producer of natural gas in the world. In this case, the quotation of the dollar currency is not a strong factor in creating prices of the analyzed assets. In other markets surveyed, the USD currency is an important factor in the price formation process. The presented analysis of the Pearson's linear correlation showed that the currency market is becoming a statistically significant factor for shaping the prices of the majority of commodities. The penetration of the financial area into the sector of markets, including commodities, gives direction and shape to areas of the global economy.

The listing of commodities in the currency of dollars is one of the major examples of the financial market's impact. Not only the valuation of commodities is a coherent element combining this market with foreign exchange. The cause-and-effect nature is also an important determinant of price formation [8].

\section{Result and Discussion}

The financialization process leads to the situation when futures exchanges affects the current price of commodities. The prices of diversified assets can be identified. The impact of the USD dollar exchange rate is also significant for most of them. The examined process determines the market of commodities. An open issue is the impact on other, also key products of the world economy. The financialization process also significantly contributes to the increase in market volatility and the increasing dependence of individual commodity groups on each other.

Since the beginning of this century, a significant interdependence of prices on the commodity market can be observed. The likelihood of variability fluctuations on the spot and futures markets shows synergy and market relation [5]. The strong influence of the market of timebound anchors transforms the previously occurring cycles related to changes in supply or consumption.

The financial dimension of transactions on the futures market shows the separation of commodities from reality. The lack of a physical commodities supply requirement for large number of futures transactions indicates the use of goods as financial assets [8]. The difference between the purchase and sale of assets is a determinant of trade. The decrease in the importance of the use of commodities shows the merging of the border between use and virtual trade.

The impact of spot prices on futures was the only sphere of influence of individual markets. Currently, the possibility of a relation between the forward contracts market understood as the volume of transactions or the number of open positions is also a factor that is a feedback stimulus for creating the price of assets. Such strong changes affect the existing important price factors such as consumption or production [10].

New financial instruments bring new possibilities of trading in various assets by transforming the financial market. The creation of options, swaps and futures makes the commodity market a bookmaker's activity. Current situation on the market minimalizes the role of commodities in their usefulness. Not using resources to create energy, satisfy hunger, use in jewellery or medicine spoils their usefulness. It brings commodities to investment assets whose use loses value and meaning. Only the sale and purchase price counts. Constant changes make the commodity market and other areas a platform for speculation on which the largest individuals earn, while consumers and producers lose their capital and time [2]. Trade in commodities is an end in itself. The use of the discussed assets in terms of consumption or production is a foreign process as 
part of financialization. Speculations on the futures market show that commodities are becoming the subject of financial market.

\section{Summary}

The goal of the study was to present the impact of financial investor's behavior on the level of prices of selected commodities listed on stock exchanges. Progressive financialization transforms existing financial market structures. The analyzed process significantly influences the volatility of commodity prices. The market is full of speculators who are not interested in acquiring physical assets. Huge transactions of various types of commodity subjects lead to similar price movements. The similarity of commodity market to financial assets may threaten the flow of all economic turmoil and crises. The penetration of the financial's market determinants, including the currency one, gives character and direction to the movements of the prices of many commodities. There are exceptions to this practice when there is a visible impact of the political activities of countries that are a large world exporter, as is the case on the natural gas market.

Research methodology examined by the Pearson product-moment correlation coefficient and elements of descriptive statistics have proved a large dependence between each other's commodities. The results of tests and assumptions indicate that there is a high impact of speculators and changes in the futures market in the creation of commodity prices. The effect of the future market on spot prices can be seen in the case of gold, silver, copper or oil. The impact of financial investors actions reduces the significance of real economy factors such as production or consumption, which until now were the foundation of price changes.

The uniqueness of the ongoing process lies in the fact that financialization is a completely new creation of the real economy. Until the end of the twentieth century, there was no significant impact of the financial market on the economy. At present, the process is transforming a few structures, including the commodities market. The presented study indicates that merging many markets with the financial sector results in significant relationships between assets. The high dependence of industrial goods or commodities can lead to dangerous situations. In the event of a financial crisis, the capital market may also plunge the commodities market. The domino effect in the situation of large dependencies of commodities between each other and the stock market may be a consequence of a decrease in their value at the moment of market disturbances. Structural changes in the commodity market are causing their real utility. The economic situation is not without significance for the level of dependence of commodity prices. Expansion and recovery favor the growth of links between the analyzed goods.

The development of financialization not only damages the commodity sector, but also itself. This process can lead to the destruction of money. The possibility of a decrease in the function of thesaurisation, the means of payment or the value measure may lead to disturbances on the global market. A strong connection with other assets creates a threat to the economic stability of the whole world. There is a relationship between the development of financialization and the level of changes in the prices of the researched commodities. The decline in the importance of real economy factors in shaping commodity prices is a detachment from the classical economy and its transformation into financial determinants only. The lack of restrictions in trading on the commodity market may have a negative impact on the stability and liquidity of the global economy. Manufacturers and consumers are at risk. Commodities have become the subject of colossal speculation, the consequences of which may affect the entire economy.

\section{References}

1. Basak, S., and A. Pavlova. A Model of Financialization of Commodities, 2015, www.faculty.london.edu/apavlova/Commodities.pdf, accessed November 17, 2019. 
2. Battiston, S., M. Guerini, M. Napoletano, and V. Stolbovaa. Financialization in EU and the effects on growth, inequality and financial stability, 2018, https://www.isigrowth.eu/wpcontent/uploads/2018/07/working_paper_2018_36.pdf, accessed November 7, 2019.

3. Borcuch, A. Finansjalizacja gospodarstw domowych jako zewnętrzny efekt finansjalizacji gospodarki, https://www.coin.wne.uw.edu.pl/jgorski/eurozone/prezentacje/Dr_Borcuch.pdf, accessed July 4, 2019.

4. Chari, V., and L. J. Christiano. Financialization in Commodity Markets, Working Paper (15) 2017, Federal Reserve Bank of Chicago, 2017.

5. Chiaiel, S. D., L. Ferrara, and D. Giannone. Common Factors of Commodity Prices, Banque de France, 2017, pp. 13-19, https://www.banque-france.fr/sites/default/files/medias/documents/ wp645.pdf, accessed October 18, 2019.

6. Davis, G. F., and S. Kim. Financialization of the Economy, Ann Arbor, Michigan: The University of Michigan.

7. Dembinski, S. H. Finanse po zawale, Warszawa: Studio Emka, 2011.

8. Epstein, G. A. (ed.). Financialization and the World Economy, Edward Elgar Publishing Limited, Cheltenham, 2015.

9. Falkowski, M. Financialization of commodities, Contemporary Economics 5 (4), 2011, pp. 4-17. 10. Goldstein, I., and L. Yang. Commodity Financialization and Information Transmission, 2018, www.rady.ucsd.edu/ docs/seminars/Itay\%20Goldstein\%20-\%20Abstract.pdf, accessed October 18, 2019.

11. Jo, Y., J. Kim, and F. Santos. The Impact of Chinese Interbank Liquidity Risk on Global Commodity Markets, 2018, https://www.jiheekim.net/files/commodity.pdf, accessed October 28, 2019

12. Król, J. Giełdy towarowe - historia, zasady działania i rola we współczesnej gospodarce, Studia i prace wydziału nauk ekonomicznych i zarządzania 37 (1), 2014, p. 11.

13. Orłowska, R., and K. Żołądkiewicz (eds.). Globalizacja i regionalizacja $w$ gospodarce światowej, Warszawa: PWE, 2012.

14. Palley, T. I.. Financialization: What it is, Why it Matters, IMK Working Paper, (4) 2008., HansBöckler-Stiftung, Institut für Makroökonomie undKonjunkturforschung (IMK), Düsseldorf.

15. Ratajczak, M. Finansjalizacja gospodarki: Wymiary dyskusji, Bezpieczny bank 3 (68), 2017, pp. 7-22.

16. Russi, L. Hungry Capital - The financialization of food, Washington: Zero books, 2013.

17. Tomaszewski, D. Finansjalizacja a zmiany strukturalne na rynku towarów rolnych w pierwszych latach XXI wieku, Annales, Universitatis Mariae Curie-Skłodowska, Lublin - Polonia XLIX (4), Sectio H, 2015, pp. 601-610.

18. United Nations Conference on Trade and Development, www.unctadstat.unctad.org.

19. Zaremba, A. Makroekonomiczne determinanty stóp zwrotu na rynkach surowców w warunkach finansjalizacji, Finanse 7, 2014, pp. 69-96. 